(Professor A Cao, personal communication). Thus one oligonucleotide probe would be sufficient to carry out prenatal diagnosis on most families "at risk" in these populations. Things will almost certainly be more complicated, however, for the mainland populations of Europe and South East Asia.

With technical change so rapid what is the best approach for setting up a new prenatal diagnosis service in populations where thalassaemia is common? The first step must be education of the population (and its doctors, politicians, and religious leaders) about the disease and why a programme of prevention is important. If, in the long term, the aim is early diagnosis in the first trimester screening programmes may be necessary for school leavers or massive publicity will need to be mounted to encourage women to present early in pregnancy -self evidently, early diagnosis is possible only if women are seen early.

Until we know more about the safety of trophoblastic biopsy and the technical problems of oligonuclentide probe analysis it may be wiser not to start out with these new methods. The simplest approach is to choose the technique which is most appropriate for the skill and clinical requirements of the individual centre. Fetal blood sampling is relatively safe and of proved value. In laboratories with the appropriate technical skills DNA obtained from amniotic fluid cells may be used to make a prenatal diagnosis, either by restriction fragment length polymorphism linkage or by direct gene analysis if the molecular defect happens to be amenable. Once the service is running well it should be fairly easy to change to first trimester diagnosis if and when the methods have been proved to be safe and effective and the population has been educated about reporting early in pregnancy.

A good example of this general strategy is described on page 1327. Throughout South East Asia fetal hydrops is commonly due to the homozygous inheritance of a form of $\alpha$ thalassaemia which results from a deletion of both $\alpha$ globin genes. ${ }^{1516}$ This condition causes fetal death late in pregnancy or at term and is associated with serious obstetric complications. The Hong Kong group have shown that they can make the diagnosis by direct analysis of the $\alpha$ globin genes in fetal DNA obtained from amniotic fluid cells without culture. The defect is easy to identify by gene mapping, and the widespread use of this approach should cut short many difficult pregnancies in South East Asian populations.

Over the next few years it should be possible to simplify the techniques of trophoblast biopsy and direct gene analysis using oligonucleotide probes so that they may be carried out in many laboratories. These exciting advances have implications far beyond the diagnosis of thalassaemia. Recently, several other medically important genes have been isolated and gene probes constructed, ${ }^{17-19}$ and restriction fragment length polymorphism linkages have been obtained for disorders in which the biochemical basis is as yet unknown, such as Huntington's chorea ${ }^{20}$ and Duchenne muscular dystrophy. ${ }^{21}$ The encouraging progress made in the prenatal diagnosis of thalassaemia suggests that it will not be long before direct gene analysis is feasible for the detection of carriers and prenatal diagnosis of many single gene disorders. Whether the medical services in the developed countries, let alone the Third World, will be able to cope with the organisational problems these advances will bring remains to be seen.

D J WEATHERALL

Nuffield Professor of Clinical Medicine,

University of Oxford,

MRC Molecular Haematology Unit,

John Radcliffe Hospital,

Oxford OX3 9DU
1 World Health Organisation Working Group. Hereditary anaemias: genetic basis, clinical features, diagnosis, and treatment. Bull WHO $1982 ; 60: 643-60$.

2 Alter BP. Prenatal diagnosis of haemoglobinopathies: a status report. Lancet 1981 ;ii:1152-5.

${ }^{3}$ Weatherall DJ. The new genetics and clinical practice. London: Nuffield Provincial Hospitals Trust, 1982.

' Kazazian HH, Phillips JA, Boehm CD, Vik TA, Mahoney MJ, Ritchey AK. Prenatal diagnosis of $\beta$-thalassemias by amniocentesis: linkage analysis using multiple polymorphic restriction endonuclease sites. Blood 1980;56:926-30.

${ }^{5}$ Chang JC, Kan YW. A sensitive new prenatal test for sickle-cell anemia. $N$ Engl f Med 1982;307:30-2.

${ }^{6}$ Boehm CD, Antonarakis SE, Phillips JA, Stetten G, Kazazian HH Jr. Prenatal diagnosis using DNA polymorphisms. Report on 95 pregnancies at risk for sickle-cell disease or $\beta$-thalassemia. $N$ Engl $\mathcal{F}$ Med 1983;308:1054-8.

; Williamson R, Eskdale J, Coleman DV, Niazi M, Loeffler FE, Modell BM. Direct gene analysis of chorionic villi: a possible technique for first-trimester antenatal diagnosis of haemoglobinopathies. Lancet $1981 ;$;i: $1125-7$.

${ }^{8}$ Old JM, Ward RHT, Petrou M, Karagozlu F, Modell B, Weatherall DJ. First-trimester fetal diagnosis for haemoglobinopathies: three cases. Lancet 1982 ;ii:1413-6.

${ }^{9}$ Goossens M, Dumez Y, Kaplan L, et al. Prenatal diagnosis of sickle-cell anemia in the first trimester of pregnancy. $N$ Engl $\mathrm{F}$ Med 1983;309: 831-3.

${ }^{10}$ Orkin SH, Kazazian HH Jr, Antonarakis SE, et al. Linkage of $\beta$-thalassaemia mutations and $\beta$-globin gene polymorphisms with DNA polymorphisms in human $\beta$-globin gene cluster. Nature 1982;296:627-31.

${ }^{11}$ Jeffreys AJ. DNA sequence variants in the Ggamma-Agamma-delta- and beta-globin genes of man. Cell 1979;18:1-10.

${ }^{12}$ Old JM, Petrou M, Modell B, Weatherall DJ. Feasibility of antenatal diagnosis of $\beta$ thalassaemia by DNA polymorphisms in Asian, Indian, and Cypriot populations. $\mathrm{Br} \mathcal{F}$ Haematol (in press).

${ }^{13}$ Conner BJ, Reyes AA, Morin C, Itakura K, Teplitz RL, Wallace RB.

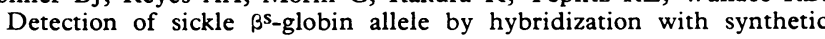
oligonucleotides. Proc Natl Acad Sci USA 1983;80:278-82.

14 Wainscoat JS, Old JM, Weatherall DJ, Orkin SH. The molecular basis for the clinical diversity of $\beta$ thalassaemia in Cypriots. Lancet 1983;i: 1235-7.

${ }^{15}$ Lie-Injo LE. Alpha-chain thalassemia and hydrops fetalis in Malaya: report of five cases. Blood 1962;20:581-90.

${ }^{16}$ Pressley L, Higgs DR, Clegg JB, Weatherall DJ. Gene deletions in alpha thalassemia prove that the $5^{\prime}$ zeta locus is functional. Proc Natl Acad Sci USA 1980;77:3586-9.

${ }_{17}$ Choo KH, Gould KG, Rees DJG, Brownlee GG. Molecular cloning of the gene for human anti-haemophilic factor IX. Nature 1982;299: 178-80.

${ }^{18}$ Woo SLC, Lidsky AS, Guttler F, Chandra T, Robson KJH. Cloned human phenylalanine hydroxylase gene allows prenatal diagnosis and carrier detection of classical phenylketonuria. Nature 1983;306:151-5.

${ }^{19}$ Kidd VJ, Wallace RB, Itakura K, Woo SLC. $\alpha_{1}$-Antitrypsin deficiency detection by direct analysis of the mutation in the gene. Nature 1983; 304:230-4.

${ }^{20}$ Gusella JF, Wexler NS, Conneally PM, et al. A polymorphic DNA marker genetically linked to Huntington's disease. Nature 1983;306: 234-8.

${ }^{21}$ Murray JM, Davies KE, Harper PS, Meredith L, Mueller CR, Williamson $R$. Linkage relationship of a cloned DNA sequence on the short arm of the $\mathrm{X}$ chromosome to Duchenne muscular dystrophy. Nature 1982; $300: 69-71$.

\section{Marathon medicine}

The modern cult of marathon running owes more to Robert Browning and his Victorian romanticism than to any recognisable historical fact. ${ }^{2}$ The marathon was not an event in the classic ancient Olympic games, but the poet's licence with the story of the Greek messenger Pheidippides's heroic run, garnished with his death as he gave the message, led to the modern Olympic marathon and some 70 years later to the mass marathon phenomenon.

The myth of the runner's death is still perpetuated as a medical fact by Northcote, who advocates routine exercise electrocardiography on all novice runners over 40 , and even some of $35-40 .{ }^{3}$ Indeed, the Victorian image of the marathon runner, close to death, is widely accepted and has been helped along by journalists. First came the collapse of Dorando 
Pietri in front of the royal box as he led the 1908 Olympic marathon, and the photograph of his being helped across the finish line became a sports classic. Pictures of Jim Peters disorientated and confused from hyperthermia as he led the 1954 Vancouver marathon in weather conditions far too hot for such an event are also frequently shown, giving the impression that marathon running is inherently dangerous.

The reality is very different. The common medical risks of marathon running and training are not alarming and they can be prevented ( $p$ 1355). For women marathon training produces a small "risk" of amenorrhoea, but the commonest reason for withdrawal from the London marathon (for either sex) in the four months to date has been pregnancy. Most problems on the day are trivial: blisters, chafing from constant friction with fashionable nylon running shorts and vests, muscle cramps, and exhaustion make up the vast majority of "casualties" recorded at popular marathons. ${ }^{4}$ These are preventable to some extent by adequate training, correct shoes and clothing, and perhaps use of petroleum jelly on friction points. Musculoskeletal problems are common during training, and more than a third of these are knee injuries, which often become chronic. ${ }^{5}$ Accurate diagnosis of musculoskeletal problems is not possible in a "major disaster" setting with 1000 or more casualties at first aid stations at popular marathons, so that the actual incidence of fatigue fractures is not known, but fractures of the neck of the femur as well as the commoner "march fractures" may occur.

Constitutional problems are usually related to the weather and dehydration. Heat stroke may occur even in mild weather conditions, but hypothermia is commoner in Britain. Apart from advice on drinking frequently and wearing adequate clothing in cold weather, the prevention of real damage from hyperthermia probably requires education of the public not to encourage the dazed disorientated runner to carry on but to get him to first aid as soon as possible.

Major cardiac events are surprisingly uncommon, and the occasional death from heart disease is perhaps inevitable with the numbers of participants. ${ }^{6-8}$ Canadian experience of exercise testing has shown it to be of very limited cost benefit in mass screening of potential joggers. Such tests tend to give frequent false positive results in normal populations, and a better approach uses a preliminary health questionnaire to identify those at particularly high risk. ${ }^{9}$ The best form of prevention is better public knowledge of coronary disease and its symptoms. Inevitably occasional death in a marathon is given a great deal of press coverage ${ }^{8}$ but necropsy usually shows extensive coronary disease. ${ }^{11}$ Possibly we are all susceptible to the legend of Pheidippides, but over $96 \%$ of the 36000 runners in the last two London marathons finished the course, and perhaps after a century this romantic legend will be laid to rest.

\section{Dan Tunstall Pedoe}

Senior Lecturer and Consultant in Medicine and Cardiology,

St Bartholomew's Hospital,

London EC1A 7BE and

Medical Director London Marathon

${ }^{1}$ Grogan R. Run Pheidippides, run. The story of the battle of Marathon. Br $\mathcal{F}$ Sports Med 1981;15:186-9.

" Martin DE, Benaria HW, Gynn RWH. Development of the marathon from Pheidippides to the present with statistics of significant races. Ann NY Acad Sci 1977;301:820-57.

${ }^{3}$ Northcote RJ, Ballantyne D. Sudden cardiac death in sport. Br Med $\mathcal{F}$ $1984 ; 287: 1357-9$.

${ }^{4}$ Nicholl JP, Williams BT. Injuries sustained by runners during a popular marathon. Br $\mathcal{F}$ Sports Med 1983;17:10-5.

${ }^{5}$ Maughan RJ, Miller DB. Incidence of training related injuries among marathon runners. Br $\mathcal{F}$ Sports $M e d$ 1983;17:162-4.
"Williams RS, Schocken DD, Morey M, Koisch FP. Medical aspects of competitive distance running. Postgrad Med $1981 ; 70: 41-50$.

; Tunstall Pedoe DS. Cardiological problems in sport. $\mathrm{Br} \mathcal{F}$ Hosp Med 1983;29:213-20.

* Tunstall Pedoe DS. Exaggerated risk of marathon races. The Times 1983 June $27: 9(\operatorname{col} 7)$.

"Shephard RJ. Can we identify those for whom exercise is hazardous? Sports Medicine 1984;1:75-86.

1" Parsons MA, Anderson PB, Williams BT. An "unavoidable" death in a people's marathon. Br $\mathcal{F}$ Sports Med 1984;18:38-40.

11 Waller BF, Roberts WC. Sudden death while running in conditioned runners aged 40 years or over. Am f Cardiol 1980;45:1292-300.

\section{The dynamic approach to residential care of the disabled}

Disabled people, it is often said, should be able to choose how to live-just as the rest of us do; and indeed even the most severely handicapped can now be enabled to live in the community. But many disabled people have to be content with residential care because they cannot marshal the intensive support they would need at home. Others becone too exhausted or incapable to organise themselves, and some just want the companionship of a group. The individual stories of those who succeed in the community show how much toughness is called for. ${ }^{1}$

Improving the quality of life in residential settings and creating links with the community for those who all too easily feel outcasts is, then, important and was the theme of a recent seminar, held in London under the patronage of the European Community, on "The Dynamic Approach to the Residential Care of Disabled People in an Integrating Society." Among the more general topics discussed were choice and opportunity, flexibility, and independence and the need for more research and better dissemination of information.

The general requirements were well summarised by A Klapwijk from the Netherlands: making plans always in conjunction with the disabled people themselves, remembering that it is their life; offering a choice of living arrangements, and providing for privacy; making both medical and other services and social facilities readily available; and having a system of funding that makes for easy transfer from one type of accommodation to another. Choice means money among other things and, said several speakers, people should have the money to spend on the kind of care they want, in or out of the community. But there was the proviso that funds need to go directly to institutions as well as to individuals to provide a short term haven for emergencies and intermittent relief and facilities for repeated assessments and rehabilitation.

For residential care, as John Wedgwood emphasised, should no longer be thought of as a static or all or nothing affair. Long term care, short term or intermittent care, and outpatient or day care may coexist in a single unit or institution, giving a service that is both more economical and more appropriate $^{2}$; one person may make use of all the types of care at different times. This kind of blurring of boundaries needs to be encouraged. The 300 Netherlands "nursing institutes" provide not only long term care but also day care for people who are independent or in special accommodation in the community and they admit those who become more incapacitated; there is also an invaluable facility for admission for limited periods-within hours in an emergency. 